Note on West-African Species of Hemirhamphus. By Dr. A. Günther.

I have just observed that I omitted, in my account of Hemirham. phus, to mention the West-African species described and figured by Dr. Bleeker in “Poissons de la Côte de Guinée," Mém. Soc. Holl. Haarlem, 1862.

1. The species described by him (p. 118, tab. 21. fig. 2) as $H$. vittatus (Val.), and identified with Esox brasiliensis (Brown), is most probably the Linnean Esox brasiliensis (see Catal. Fish. vi. p. 270), but distinct from $H$. vittatus (Val.).

2. Hemirhamphus guineensis, n. sp., Blkr. p. 119, tab. 25. fig. 2, is identical with $H$. vittatus (Val.), Günth. Fish. vi. p. 269.

3. Hemirhamphus Schlegelii, Blkr. p. 120, tab. 25. fig. 1, is a very distinct species, to which I have, unfortunately, given another name, viz. H. calabaricus (Fish. vi. p. 266).

\title{
On the Organs of Secretion in the Hemiptera.
} BY J. KüNCKEL.

The most voluminous of the salivary glands are supported on the stomach, and occupy the whole upper part of the thoracic cavity, and extend into the abdomen. Each of them is divided into two parts by a constriction, and from this point the ejaculatory duct issues beneath. This duct divides at once into two branches, the largest of which runs almost directly to the head, passing beneath the œsophagus, where it approaches that of the opposite side. These ducts become fixed in a small cylindrical piece, of solid texture, and finally open by distinct orifices. The smaller branch descends into the abdomen, forming numerous sinuosities, and then ascends towards the head; on arriving in front of the œsophagus, being suddenly turned aside, it passes beneath a large coriaceous piece, which plays a great part in the movements of the parts of the mouth and in the acts of suction and deglutition.

The glands of the second pair, concealed beneath the principal glands, are formed each of a simple cæcal tube rolled upon itself and terminating at the outer angle of the coriaceous piece just mentioned.

The superior salivary apparatus contains a secreting membrane covered throughout with utricles of equal size. The anterior part, often inflated, looks as if it formed a reservoir for the hinder part, which is generally racemose; but this is not the case, as the histological constitution shows that the same functions are performed by both parts. The second salivary apparatus shows much analogy with the preceding in its structure, but its utricles are more scattered. The two glands of which it is formed are the seat of a special secretion, and not, as supposed by Léon Dufour, reservoirs for that of the superior glands. The salivary secretion, when introduced into plants, produced none of the effects ascribed to the attacks of Hemiptera. 


\section{$2 \mathrm{BHL}$ Biodiversity Heritage Library}

Günther, Albert C. L. G. 1866. "Note on West-African species of Hemirhamphus." The Annals and magazine of natural history; zoology, botany, and geology 18, 427-427.

View This Item Online: $\underline{\text { https://www.biodiversitylibrary.org/item/53284 }}$

Permalink: https://www.biodiversitylibrary.org/partpdf/51171

\section{Holding Institution}

Smithsonian Libraries

\section{Sponsored by}

Smithsonian

\section{Copyright \& Reuse}

Copyright Status: Public domain. The BHL considers that this work is no longer under copyright protection.

This document was created from content at the Biodiversity Heritage Library, the world's largest open access digital library for biodiversity literature and archives. Visit BHL at https://www.biodiversitylibrary.org. 